\title{
Destinasyon Pazarlaması Kapsamında Bilecik Ili Turizminin Değerlendirilmesine Yönelik Paydaş Analizi
}

\author{
Stakeholder Analysis to Evaluate Tourism in Bilecik within Scope of Destination \\ Marketing
}

Ahmet VATAN*

Burhanettin ZENGIN***

\begin{abstract}
$\ddot{O} Z$
Dünya'da turist sayısının her geçen gün artması, destinasyonlar arasındaki rekabeti de arttırmaktadır. Bu sebeple her destinasyon kendini rakip destinasyonlardan ayrıştıran farklı yönlerini ön plana çıkarıp rekabette üstünlük sağlamayı amaç edinmektedir. Destinasyonu farklılaştırma amacl, destinasyon pazarlamasının önem kazanmasında büyük rol oynamaktadır. Destinasyonlar, konumlandırma, imaj ve markalama çalışmaları ile etkin bir destinasyon pazarlaması gerçekleştirmeyi hedeflemektedirler. Bu çalışmanın amacı, destinasyon pazarlaması kapsamında Bilecik İlinin bir turizm destinasyonu olarak daha etkin nasıl pazarlanabileceğinin paydaşlar bakış açısı ile tespit etmektir. Çalışmanın kapsamı Bilecik'te var olan turizm paydaşlarıdır. Araştırma kapsamındaki paydaşlar ile yar yapılandırılmış mülakat gerçekleştirilmiştir. Toplanan veriler, nitel veri analiz yöntemlerinden betimsel analize tabi tutulmuş ve elde edilen bulgular destinasyon pazarlaması çerçevesinde tartışılmıştır. Çalışma sonucunda paydaşların Bilecik İline dair pazarlama çalışmalarını yeterli bulmadıkları gözlenmiştir. Bununla birlikte Bilecik'in bir turizm destinasyonu olarak etkin pazarlanabilmesi için destinasyon konumlandırması, destinasyon imajı ve destinasyon markalaması vb. konularda daha kapsamlı çalışmaların yapılması gerektiği söylenebilir.
\end{abstract}

\section{ANAHTAR KELIMELER}

Destinasyon Pazarlaması, Imaj, Marka, Konumlandırma, Bilecik

\begin{abstract}
Competition between the destinations also increases with the increasing tourism demand. Therefore, each destination aims to bring its different aspects from the rival destinations to the forefront and provide superiority in the competition. The destinations aim to realize effective destination marketing with positioning, image and branding studies. The aim of this study is to detect how Bilecik will be marketed more effectively within the scope of destination marketing as a tourism destination with the opinions of the stakeholders. In the regard, semi-structured interview is made with stakeholders within the scope of research. The data collected is analyzed with the descriptive analysis method, of the qualitative analysis methods, and findings obtained are discussed within the frame of destination marketing. As result of the study, marketing studies for Bilecik are not sufficient. It is necessary to conduct studies on the subjects such as destination positioning, destination image and destination branding for an effective marketing of Bilecik as a destination.
\end{abstract}

\section{KEYWORDS}

Destination Marketing, Image, Brand, Positioning, Bilecik

\begin{tabular}{|c|c|c|}
\hline \multicolumn{2}{|r|}{$\begin{array}{c}\text { Makale Geliş Tarihi / Submission Date } \\
\text { 24.02.2019 }\end{array}$} & $\begin{array}{c}\text { Makale Kabul Tarihi / Date of Acceptance } \\
\text { 02.04.2019 }\end{array}$ \\
\hline Attf & $\begin{array}{l}\text { Vatan, A. ve Zengin, B. (2019). Desti } \\
\text { Yönelik Paydaș Analizi. Selçuk Üniver }\end{array}$ & $\begin{array}{l}\text { apsamında Bilecik İli Turizminin Değerlendirilmesine } \\
\text { Meslek Yüksekokulu Dergisi, } 22 \text { (1), } 272 \text { - } 288 .\end{array}$ \\
\hline
\end{tabular}

\footnotetext{
* Dr. Öğr. Üyesi, İstanbul Medeniyet Üniversitesi, Turizm Fakültesi, Turizm İşletmeciliği Bölümü, ahmet.vatan@ medeniyet.edu.tr, ORCID: 0000-0002-9741-3287

*** Doç. Dr., Sakarya Uygulamalı Bilimler Üniversitesi, Turizm Fakültesi Turizm Rehberliği Bölümü, bzengin@ sakarya.edu.tr, ORCID: 0000-0002-6368-0969
} 


\section{GİRIŞ}

Yer pazarlaması olarak ifade edilen destinasyon pazarlaması, 'bir alanı, bir bölgeyi ya da bir yeri, kişilere ya da kurum ve kuruluşlara çekici, uygun ve özellikli olduğunu göstermek amacıyla yapılan pazarlama faaliyetlerinin bütünü” olarak tanımlanmaktadır (Dacko, 2008: 389). Turizm pazarlamasının modern anlayışa geçmesinin ürünü olan destinasyon pazarlaması, coğrafi olarak bir bölge veya kenti kapsamakta ve genellikle ulusal düzeydeki pazarlama çabalarının bir unsuru olmaktadır. Destinasyon pazarlamasının amacı, destinasyona yönelik turizm talebini şekillendirmek olarak tanımakla birlikte; destinasyonlar son yıllarda artan uluslararası pazar rekabeti dolayısıyla yoğun biçimde markalaşma çabası içinde bulunmaktadırlar. Yoğun rekabet ortamında destinasyonların fark edilmesi için dikkat çekici ve farklı bir imaj ile ön plana çıkararak pazarlama çalışmalarını yürütmeleri gerekmektedir (Efsun ve Arslan, 2009: 100-101).

Son dönemlerde "marka şehir" kavramına sıklıkla rastlanmaktadır. Bunun sebebi destinasyon pazarlamasının giderek önemini arttırmasıdır. Destinasyonun başarısını etkileyen en önemli unsurlar arasında destinasyon pazarlamasının unsurları yer almaktadır. Destinasyon pazarlaması unsurları, bağımsız olmayıp birbirinin içine geçmiş olarak değerlendirilmektedir. Hedeflenen pazarı oluşturan kişi veya kurum ve kuruluşların zihninde, bir ürünle ilgili imaj yaratma süreci olarak tanımlanan konumlandırma; insanların herhangi bir ürüne dair edindikleri izlenimler, bilgiler ve o ürünle ilgili sahip oldukları hissiyat ve fikirlerin toplamını ifade eden imaj; ürünü tanımlayan ve farklılaştıran slogan, logo, işaret veya benzeri elemanların birleşimi olan marka destinasyon pazarlamasının unsurları arasında yer almaktadır.

Son yıllarda destinasyon ve destinasyon pazarlaması ile ilgili gerek ulusal gerekse uluslararası proje ve uygulamaların hızla arttı̆ı görülmektedir. Destinasyon pazarlaması kapsamında Bilecik turizminin değerlendirilmesini kapsayan bu çalışmayla; Bilecik turizminin, paydaşların bakış açısı ile destinasyon pazarlaması çerçevesinde nasıl değerlendirildiği ve paydaşların Bilecik'in bir turizm destinasyonu olarak daha etkin nasıl pazarlanabileceği konusundaki düşünceleri araştırılmaya çalışılmıştır.

\section{DESTINASYON PAZARLAMASI}

Destinasyon pazarlaması, belirli bir bölgenin popülerliğinin dayandığı ve popülerliğini artırdı̆̆ tamamlayıcı bir parçadır. Ancak turizm planlayıcılar sıklıkla destinasyon gelişmelerine odaklanırken turisti destinasyona çeken özellikleri belirleme ve korumayı göz ardı etmektedir (Kotler ve diğ., 2006: 214). Destinasyonların pazarlanması, coğrafi açıdan ele alınacak olursa; bir kenti ya da bir bölgeyi kapsamaktadır ve genel olarak ulusal bir pazarlama faaliyetinin unsuru olarak görülmektedir (Ersun ve Arslan, 2011: 236).

Destinasyon pazarlaması, bir destinasyonun en yüksek şekilde kazanç elde etme hedefine uygun olarak ürettiği turistik ürünlerin hedef pazarlarda bulunmasını sağlamak amacıyla turizm talebinin özelliklerini de göz önünde bulundurarak turistik ürün ile ilgili araştırma, tahmin ve seçim yapma gayesinde olan ve bu konularda ilgili karar ve uygulamaları kapsayan yönetim felsefesi olarak tanımlanabilir (Özer, 2012: 164). Turistik destinasyon pazarlamasının amacı genel olarak iki ana başlık altında toplanmaktadır. Bu amaçlar (Aktaş, 2007: 117);

- Bir destinasyonun sahip olduğu turistik ürün, hizmet ve kaynakların, en verimli kullanımına yardımcı olacak pazar ya da pazarların tespit edilmesi ve tanıtılması,

- Hedef pazardaki potansiyel turistlerin satın alma kararları, destinasyonun sahip olduğu turistik ürün ve paketlerini tercih etme yönünde etkileyecek planlama, üretim ve tanıtım çalışmalarının yapılması olarak belirtilmiştir.

- Başarılı bir destinasyon pazarlamasından söz edebilmek için; nitelik ve hizmetlerin uygun karması, hedef pazarı çekecek imajın olması, mal ve hizmetlerin etkin ve kolay yollardan dağıtımının yapılabilmesi ve ileride bölgeye gelecek ziyaretçilerin destinasyonun farklı üstünlüklerinden haberdar olmalarına yardımcı olmak amacıyla, destinasyonun itibar ve imajının etkin bir şekilde geliştirecek reklam ve tanıtımın yapılması gerekmektedir (Howie, 2003: 45).

- Ülkeler açısından büyük önem arz eden ve turistik ürün olarak kabul edilen destinasyonların doğru ve iyi bir şekilde pazarlanması ve ziyaretçiler tarafından kabul ve tercih edilmesi, rekabette ayırt edici bir unsurdur (Ceylan, 2011: 90). Ayrıca destinasyonlar sahip oldukları bütün elemanlarla bir turizm ürünü olarak düşünüldüğünde, pazarlama açısından zor ve pahalı bir süreci de ifade etmektedir (Duman ve Öztürk, 2005: 10).

- Destinasyon pazarlamasında başarıya ulaşabilmek için destinasyon pazarlayıcılarının aşağıdaki konulara dikkat etmesi gerekmektedir (King, 2002: 106);

- Hedef kitle üzerinde olumlu izlenim uyandırabilecek güçlü bir marka imajı oluşturulmalıdır, 
- Turistlerin ihtiyaç, beklenti ve onları destinasyona motive eden faktörlerin tam olarak belirlenmesi ve müşteri memnuniyetinin sağlanabilmesi amacıyla tüketicilerin ihtiyaçları araştırılmalıdır,

- Destinasyon pazarlamasının başarılı ve kalıcı olabilmesi için önemli olan konulardan birisi de tüm iletişim kanallarının açık tutulması ve kilit noktadaki turistlerle doğrudan irtibat halinde olunmasıyla turistlerin tüm gelişmelerden haberdar edilmesi gerekmektedir,

- Tüketicileri haberdar etmek adına pazarlama faaliyetlerinde tüketici deneyimlerine yer verilmelidir,

- Tutundurma faaliyetleri daha etkili iletişimin oluşmasını kolaylaştırır.

- Başarılı bir destinasyon pazarlamasından söz edebilmek için; destinasyon pazarlama unsurlarının etkin kullanılması gerekmektedir. Destinasyon pazarlama unsurları imaj, marka ve konumlama olarak siralanmaktadir (Arslan, 2008: 89).

\section{DESTINASYON PAZARLAMASI UNSURLARI (BİLEŞENLERİ)}

Destinasyon pazarlama unsurları bir bütünü oluştururken, bütünden ayrıştığında da kendi başına anlam taşıyan parçalardır. Konumlama, imaj ve marka bir araya gelerek destinasyon pazarlamasının başarıya ulaşmasında bütünü oluşturur. Destinasyon pazarlama unsurları kendi başlarına da anlam taşıdıkları için destinasyon pazarlanırken her biri detaylı şekilde ele alınmalıdır.

Konumlandırma, mal ya da hizmetin pazardaki rakiplere karşı üstünlük sağlayacak şekilde farklılaştırılması ve tüketici zihninde bu farklılığın ve ürünün markasının algılanmasını sağlamaktadır (Brooksbank, 1994: 10). Bir ürünün konumu o ürünün tüketiciler tarafından nasıl tanımlandığı ile ilgilidir ve rakip ürünlere göre tüketicinin zihninde işgal ettiği yeri temsil etmektedir (Kotler ve Armstrong, 2006: 216). Bir ürünün veya işletmenin konumu, pazardaki rakip ürünlerle karşılaştırıldığında tüketicilerin sahip oldukları duyguların ve düşüncelerin algısal bütünüdür (Huybers ve Bennett, 2003: 573). Bir destinasyon konumlandırma stratejisinin aşamaları sıralanan şekilde gerçekleşmektedir (Crompton ve diğ., 1992: 20):

- Rekabetçi destinasyonları belirlemek,

- Potansiyel ziyaretçilerin destinasyonun güçlü ve zayıf yanlarına ilişki algılarını belirlemek,

- Hedef pazardaki potansiyel ziyaretçiler tarafından elde edilecek faydaları belirlemek,

- Potansiyel ziyaretçilerin tercih edilen rekabetçi destinasyonun güçlü ve zayıf yanlarına ilişkin algılarını belirlemek,

- Potansiyel ziyaretçilerin destinasyonu rakiplerine göre nasıl algıladığını belirlemek,

- Destinasyon için en elverişli konumu seçmek.

Bir destinasyonun herhangi bir pazar diliminde konumlanması; destinasyonun sahip olduğu ürünün turistlerin zihninde yarattığ ve turistlere ifade ettiği değerlerin toplamı anlamına gelmektedir. Pazarlama çabaları olmadan da turistlerin bir destinasyonu zihinlerinde belli bir yere konumlamaları mümkündür. Ancak doğru konumlama için, hedef pazar ve bu pazarı oluşturan turistlerin ihtiyaçlarını ve beklentilerini bilmek önemlidir. Destinasyonların kendilerini potansiyel turistlerin algısında nasıl konumlandıracağının kararı destinasyonların turizm piyasasındaki rekabet güçlerini etkiler ve belirler. Dolayısı ile bir destinasyon nasıl bilinmek, tanınmak ve hatırlanmak istiyorsa konumlandırmanın da o yönde olması gerekmektedir. Bu amaçla destinasyonların rakiplerinden farklılaştırılması ve cazip hale getirilmesi için doğru ve uygun bir imaj oluşturulması önemlidir (Bardakoğlu, 2011: 87).

Dünya üzerindeki birçok destinasyon (ülke veya şehir) planlı ya da plansız şekilde kitlelerin zihinlerinde belli konumlarda bulunmaktadırlar. Las Vegas denince kumar, Paris denince aşk ve romantizm, İtalya denince moda ve Vietnam denince savaş akla gelmesi bu durumu açıklayan en açık örneklerdir. Vietnam, çok zengin bir mutfak kültürüne sahip bir ülke olmasına rağmen zihinlerdeki algılama otuz yıl önce bitmiş savaş konusunda takılmış durumdadır. Tüketiciler, çeşitli destinasyonlar ile ilgili olayları haberler, filmler ve etrafindaki kişilerden çok fazla araştırma yapmadan edinmektedir (İpar, 2011: 169).

Destinasyon konumlana, destinasyonlar için imaj inşa ederek ve bu imajların sürdürülebilirliğini sağlayarak pazarlamacılara belirli stratejiler geliştirmesi ve uygulaması hususunda yardımcı olmaktadır. Ancak destinasyon pazarlayıcılarının açısından bakıldığında var olan destinasyon konumlandırmaları uygun bulunmakta ya da istenen pazarlama hedeflerine ulaşmada yeterli olmayacağı düşünülmektedir. Destinasyon konumlandırması yapabilmek için turistlerin tercih ve algı düzeyleri üzerinde bilimsel araştırma yapılmalıdır. $\mathrm{Bu}$ tercihler daha sonra söz konusu destinasyonun tanıtımına katkı saylayabilir ve sonuç olarak ihtiyaç duyulursa yeni ve karlı bir konumlandırma yapılabilir (Sarma, 2014: 104).

İmaj sözcügü̆, hedef kitleyi oluşturan tüketicilerin çoğunluğunun ülke, ürün veya marka ile ilgili düşünceleri ve değer yargıları olarak ifade edilebilmektedir (Aaker ve Keller, 1990: 27). İmajın anlamı ve ölçümüyle ilgili uzun yıllardır devam eden akademik çalışmalara rağmen, gerek destinasyonların imaj 
biçimlenme süreci hakkında ve gerekse doğası hakkında bir fikir birliğine varılmamıştır (Echtner ve Ritchie, 1993: 4).

İmaj kavramının sözlük anlamı "zihinsel görüş, algılanma ya da fikirdir". İmaj, bir nesneye (bir ürüne, markaya, ülkeye) bakan ve onu algılayan ve değerlendiren kişinin zihninde oluşur. İmaj, bu nesneyi özetleyen temsili bir resim, nesnenin ne olduğunun kavranmasını ve hatırlanmasını sağlayan sembolik anlamlar sistemidir. İmaj, bireyin zihninde bazı öğelerin etkileşimi sonucu yavaş yavaş oluşan bir imgedir. Diğer bir ifade ile imaj, kişisel algılamaları yansıtarak, inançların, fikirlerin ve etkilerin birleşiminden oluşmaktadır (İlban ve diğ., 2008: 107).

Destinasyon imaj1, tüketicilerin bir destinasyona yönelik sahip olduğu bilgi ve duygusal düşünceleri olarak tanımlanabilir. Destinasyon imajı, turistin seyahat öncesi satın alma kararı üzerinde etkili olurken; destinasyonda geçirilen zamanın ve yaşanan deneyimin ise seyahat sonrası davranış ve tekrar ziyaret etme niyeti üzerinde etkili olduğu kabul edilmektedir (Chen ve Tsai, 2007: 1116). Destinasyon imaj1, söz konusu destinasyonla ilgili olarak insanların inançlarının, fikirlerinin ve izlenimlerinin toplamı olarak tanımlanmakta ve bu imajın etkili olması, geçerliliğine, inandırıcıllğına, basitliğine, çekiciliğine ve ayırıcı özelliğe sahip olmasına bağlanmaktadır (Yükselen ve Güler, 2009: 23). İmaj yaratma ve yönetme işinin temelinde etkin iletişim bulunmaktadır. Verilmek istenen imaj doğru medya kanalları ile doğru yer ve zamanlarda verilerek etkinleştirilmelidir (Öter ve Özdoğan, 2005: 129).

Marka; "bir üründeki diğer ürünlere göre farklı özelliklere rağmen aynı ihtiyaçları karşılayabilen" olgudur. Yine marka; "talepte bulunan veya seçilmiş bir kitleye sunulan mal, servis, yer ve/veya deneyimleri" kapsayan bir kavram olarak da tanımlanmaktadır. Tüketiciyle daha sağlıklı iletişim kurmak ve tüketici beklentileri ile markanın değerleri arasında başarılı bir ilişki kurabilmek için marka kavramının üzerinde özenle durulmalıdır (Baker ve Cameron, 2008: 85).

Marka; firmaların ürünleri için spesifik imajlar geliştirmesine yardımcı olurken rakipler tarafından taklit edilememesine de yardımcı olan bir etkendir. Tüketiciler için marka, ürünün etiketi, ambalajı, rengi, dizaynı, kalitesi ve tüketiciye sunduğu yararların bileşkesini veren bir unsurdur. Tüketiciler, satın aldıkları ürünü beğenmişler ve kendileriyle özdeşleştirmişlerse; o ürünün yani markayı tekrar satın almaktadırlar. Beğenmemişler ise; o ürün ya da markayı satın almaktan kaçınmaktadırlar. Marka, ürünün nerede, hangi bölgede üretildiğini gösteren, bununla birlikte kalite güvencesi ve ürün garantisini içeren bir unsur özelliği taşımaktadır (Kocaman, 2012: 28). Marka, daha geniş alanı kapsayan bir kavramdır. Sadece işletmeler ve ürünlerini kapsamaz. Ürün ve işletmelerin yanında ülkeler (Hollanda, Amerika), şehirler (Paris, Atina) ve insanlar da (Madonna, Elvis Presley) birer markadır. Tüm insanlar da birer markadır. Çünkü marka, anlam ve çağrışımlara sahip bir etikettir (Kotler, 2004: 12).

Markanın destinasyon boyutu ise destinasyon markalamasını getirir. Destinasyon markalaması, destinasyona ilişkin tutarlı bir marka kimliği oluşturmak ve olumlu bir imaj geliştirme çalışmalarıyla markayı farklılaştırmak anlamına gelmektedir. Markanın bileşenleri marka imajı ve marka kimliğidir. Marka kimliği marka imajından daha önce gelir ve imaj oluşturmada temel noktadır. Çünkü marka imajı, marka kimliğine ilişkin algilanan bileşenlerin tüketici zihninde sentezi sonucunda oluşur (Yavuz, 2007: 49).

Destinasyon markası, bir destinasyona kimlik kazandıran ve farklılaştıran isim, sembol, logo ya da görsel gösterimler bütünü olarak tanımlanmaktadır. Destinasyon markası, tüketici tarafından yaşanan ve hatırlanan bir deneyimdir. Tüketicinin ziyaretini veya yaşanmışlığını oraya özgü marka bileşenleriyle hatırlanabilir bir deneyime dönüştüren, bu deneyimi güçlendiren ve birleştiren bir kavramdır (Caldwell ve Freire, 2004: 50). Destinasyon markası, kapsamlı bir marka stratejinsin uygulanması sonucunda oluşan ve ziyaretçilerin destinasyona özgü her türlü deneyimlerini içeren, hedef kitlesinin istek ve ihtiyaçlarını yansıtmasıyla ve onların burada yaşadığı deneyimlerle ortaya çıkan bir imaj olarak akıllarda yer tutan deneyimsel bir kavramdır. Destinasyon markası, söz konusu destinasyonla özdeşleşmiş hatırlanabilir yaşanmışlıklar, yine söz konusu destinasyonu çekici kılan özellikleri ve kaliteli yönlerinin çağrışımından oluşan sembolik bir yapıdır (Hankinson, 2004: 146).

\section{YÖNTEM}

$\mathrm{Bu}$ çalışmada nitel araştırma yöntemi kullanılmıştır. Araştırmanın ana problemi, mevcut durumun ayrıntılı ve derinlemesine araştııılmasını gerektirdiğinden, araştırmanın deseni paydaş analizi olarak belirlenmiştir. Araştırmada üstünde çalışılan durumlara ilişkin etkenler, bütüncül bir yaklaşımla ele alınarak etkileri üzerine odaklanılmıştır. Bu durumda araştırmanın ana problemine bağlı olarak "ne, ne zaman, nerede, nasıl, neden ve kim" sorularına yanıt aranmıştır. Çalışmada örneklem stratejisi belirlenirken turizm literatüründe yapılmış önceki çalışmalar incelenmiştir. Buhalis'in 2000 yılında yapmış olduğu çalışma örneklem konusunda yol 
göstermiştir. Bununla birlikte araştırma deseni olan paydaş analizine en uygun olacak örneklemin seçilmesi hedeflenmiştir. Amaçlı örnekleme yöntemleri içerisinde yer alan maksimum çeşitlilik örnekleme çalışmaya en uygun örnekleme yönetimidir. Destinasyon pazarlaması kapsamında Bilecik İli turizminin değerlendirilmesine yönelik paydaş analizi konulu çalışmanın örneklemini Bilecik İlinde yer alan paydaşlar oluşturmaktadır. Örneklemi oluşturan paydaşlar Bilecik İli milletvekilleri, vali, ilçe kaymakları, belediye başkanları, il kültür ve turizm müdürü, turizm eğitimi veren kurum yöneticileri, turizm işletmeleri yöneticileri ile yerel halk1 temsilen sivil toplum kuruluşları başkanlarıdır. Paydaşlar ile yarı yapılandırılmış mülakat gerçekleştirilmiştir. Gerçekleştirilen mülakatlar betimsel analize tabi tutulmuştur. Elde edilen bulgulardan yola çıkılarak kamu kurum ve kuruşlarına, turizm sektörüne ve sonraki araştırmacılara kaynaklık etmesi için çeşitli önerilerde bulunulmuştur.

Tablo 1. Mülakat Yapılan Yerel Paydaşlar

\begin{tabular}{|c|c|c|c|c|}
\hline Paydas & Türü & Kurum Adı / Isşletme Adl & $\begin{array}{l}\text { Mülakat } \\
\text { Tarihi }\end{array}$ & $\begin{array}{l}\text { Mülakat } \\
\text { Saati }\end{array}$ \\
\hline P1 & Özel & Grand Çalı Otel & 13.02 .2015 & 14:00 \\
\hline $\mathrm{P} 2$ & Özel & Otel Eronur & 14.02 .2015 & 14:00 \\
\hline P3 & Özel & Namlı Butik Otel & 24.02 .2015 & $11: 30$ \\
\hline $\mathrm{P} 4$ & Özel & AGM Turizm & 14.02 .2015 & 15:30 \\
\hline P5 & Özel & Fulya Turizm & 13.02 .2015 & 16:00 \\
\hline P6 & Özel & Tünel Restoran & 13.02 .2015 & $20: 00$ \\
\hline $\mathrm{P} 7$ & Özel & Acar Restoran & 03.04 .2015 & 16:00 \\
\hline P8 & Özel & Ertuğrul Gazi Derneği & 13.02 .2015 & $20: 00$ \\
\hline P9 & STK & Edebali Kültür ve Araştırma Derneği & 07.02 .2015 & 13:00 \\
\hline P10 & STK & Şeyh Edebali Derneği & 07.02 .2015 & 14:30 \\
\hline P11 & STK & $\begin{array}{l}\text { Ertuğrul Gazi’yi Anma ve Söğüt Şenliği } \\
\text { Vakfi }\end{array}$ & 16.02 .2015 & 10:00 \\
\hline $\mathrm{P} 12$ & STK & Bilecik Ticaret ve Sanayii Odas1 & 13.04 .2015 & 13:00 \\
\hline $\mathrm{P} 13$ & Kamu & Bilecik Valiliği & 10.02 .2015 & 15:00 \\
\hline $\mathrm{P} 14$ & Kamu & Bilecik Belediye Başkanlığı & 16.03 .2015 & 14:30 \\
\hline $\mathrm{P} 15$ & Kamu & Söğüt Kaymakamlığı & 16.02 .2015 & 10:00 \\
\hline P16 & Kamu & Söğüt Belediye Başkanlı̆̆ & 03.02 .2015 & 10:00 \\
\hline P17 & Kamu & Bozüyük Kaymakamlığı & 10.03 .2015 & $16: 30$ \\
\hline P18 & Kamu & Bozüyük Belediye Başkanlığı & 27.02 .2015 & 10:00 \\
\hline P19 & Kamu & Osmaneli Kaymakamlığı & 16.02 .2015 & 14:30 \\
\hline $\mathrm{P} 20$ & Kamu & Osmaneli Belediye Başkanlığı & 06.02 .2015 & 11:00 \\
\hline $\mathrm{P} 21$ & Kamu & Pazaryeri Kaymakamlığı & 04.02 .2015 & 14:00 \\
\hline $\mathrm{P} 22$ & Kamu & Pazaryeri Belediye Başkanlığı & 04.02 .2015 & $16: 30$ \\
\hline $\mathrm{P} 23$ & Kamu & Bilecik İl Kültür ve Turizm Müdürlüğü & 16.03 .2015 & 13:30 \\
\hline P24 & Kamu & Bilecik Üniversitesi & 23.03 .2015 & 13:00 \\
\hline P25 & Kamu & $\begin{array}{l}\text { Bilecik Anadolu Otelcilik ve Turizm } \\
\text { Meslek Lisesi }\end{array}$ & 06.03 .2015 & 15:30 \\
\hline $\mathrm{P} 26$ & Kamu & $\begin{array}{l}\text { Bozüyük Selahattin Şeker And. Otelcilik ve } \\
\text { Turizm M.L. }\end{array}$ & 06.03 .2015 & 10:30 \\
\hline $\mathrm{P} 27$ & Kamu & MHP Bilecik Milletvekili & 11.03 .2015 & $12: 30$ \\
\hline P28 & Kamu & AKPARTİ Bilecik Milletvekili & 15.02 .2015 & 19:00 \\
\hline
\end{tabular}


Destinasyon pazarlamasına ilişkin literatürün taranması sonucunda ortaya çıkan sorular, mülakat sürecinde kullanılan yarı yapılandırılmış mülakat formunu oluşmaktadır. Mülakat formunun güvenilir ve geçerliliğini sağlamak için uzman görüşüne ihtiyaç duyulmaktadır. Bu sebeple mülakat formu, destinasyon pazarlaması, pazarlama veya tanıtım konularında uzmanlaşmış öğretim üyelerine ulaştırılmıştır. Mülakat formu 10 uzman görüşü ile onaylandıktan sonra Bilecik İli turizm paydaşlarından telefon ile randevular talep edilmiştir. Mülakatlar Tablo 1'den de anlaşılacağı gibi 03.02.2015 tarihi ile 13.04.2015 tarihleri arasında gerçekleştirilmiştir. Randevular günün farklı saatlerinde planlanmış ve mülakatlar kişilerin makamlarında ve işletmelerde yapılmıştır. Temalar altında düzenlenen veriler doğrudan alıntılarla desteklenerek bulguların tanımlanması sağlanmıştır. Söz konusu temalar ve alt temalara, çalışmanın bulguları sunulurken detaylı olarak yer verilmiştir. Bulguların yorumlanması olan son aşamada ise elde edilen bulgular açıklanmış, ilgili çalışmanın sonuçları ile karşılaştırılarak yorumlanmıştır. Bununla birlikte görüşmelerin 2015 yılında yapılmış olması ve görüşme yapılan kişilerin halen mevcut konumda olmama ihtimali olması durumu, araştırmanın k1sitlılığ 1 olarak görülmektedir.

\section{BULGULAR VE TARTIŞMA}

Çalışmanın bu kısmında, yapılan betimsel analiz doğrultusunda elde edilen bulgular sunulmaktadır. Destinasyon pazarlaması kapsamında Bilecik İli turizminin değerlendirilmesine yönelik paydaş analizini konu alan bu çalışmanın bulguları, "yarı yapılandırılmış mülakatlardan elde edilen bulgular" başlığı altında sunulmuştur. Bilecik’ teki yerel turizm paydaşları ile gerçekleştirilen mülakatlardan elde edilen veriler, çalışma bulgularının temelini oluşturmaktadır.

Tablo 2. Oluşturulan Tema Kodları

\begin{tabular}{c|c} 
Tema Kodu & Mülakat Formu Yardımıyla Oluşturulan Temalar \\
\hline$T 1$ & $\begin{array}{c}\text { Paydaşların Bilecik Turizminin Pazarlama Çalışmaları Hakkındaki } \\
\text { Görüşleri }\end{array}$ \\
\hline$T 2$ & $\begin{array}{c}\text { Paydaşların Bilecik İlinin Bir Turizm Destinasyonu Olarak } \\
\text { Konumlandırılması Hakkındaki Görüşleri }\end{array}$ \\
\hline$T 3$ & $\begin{array}{c}\text { Paydaşların Bilecik İlinin Bir Turizm Destinasyonu Olarak İmajı } \\
\text { Hakkındaki Görüşleri }\end{array}$ \\
\hline$T 4$ & Paydaşların Bilecik İlinin Bir Turizm Destinasyonu Olarak Markalanması \\
& Hakkındaki Görüşleri
\end{tabular}

Çalışma bulgularının sunumunda çalışmanın literatür kısmında yer verilen bilgiler temel alınmıştır. Betimsel analiz, mülakat, gözlem ya da doküman inceleme veri toplama teknikleri ile elde edilmiş verilerin daha önceden belirlenmiş temalara göre özetlenmesi ve yorumlanmasını içeren bir nitel veri analiz türüdür. Bu çalışmada, daha önce belirlenen temalar ve bu temalar doğrultusunda hazırlanan sorular dikkate alınarak verilerin analizi ve bulguların sunumu yapılmıştır.

\subsection{Yarı Yapılandırılmış Mülakatlar Sonucu Elde Edilen Bulgular}

Çalışma kapsamındaki turizm paydaşları ile yapılan yarı yapılandırılmış mülakatlarda yerel paydaşların izni doğrultusunda ses kaydı alındığı için bulguları ortaya çıkarabilmek için deşifre işlemi yapılması gerekmiştir. Deşifre işlemi, bir konuşmayı yazılı veya basılı hale dönüştürme işlemi olarak tanımlanabilir. Sonuç olarak çalışmanın bu kısmında, ilgili literatürün taraması ile oluşturulan ve uzman görüşü olarak onaylanan mülakat formunda yer alan sorulara, yerel paydaşların verdiği yanıtlardan elde edilen bulgular sunulmuştur. Mülakatlara ait diğer detaylar şunlardır;

- Her mülakat ortalama 22 dakika sürmüştür,

- Toplam mülakat kayıtları 600 dakikadır,

- Mülakata çalışmada kimliklerinin beyan edilmesi noktasında paydaşlardan izin alınarak başlanmıştır.

- Mülakatlar sırasında ekstra bilgi için toplam 6 sayfa not tutulmuştur,

- Mülakat kayıtları toplam 272 sayfa ile metin haline getirilmiştir, 
- Mülakatlar toplamda 4 kategori ve 8 alt kategori halinde sunulmuştur.

\subsubsection{Paydaşların Bilecik Turizminin Pazarlama Çalışmaları Hakkındaki Görüşleri}

Bilecik turizminin pazarlama çalışmalarının değerlendirebilmesi için paydaşlara yarı yapılandırılmış mülakatlarda "Bilecik turizminin pazarlama çalışmalarını yeterli buluyor musunuz?" sorusu yöneltilmiştir. Mülakatın ilk teması bu soru yardımı ile oluşturulmuştur. Paydaşların vermiş olduğu cevaplardan çoğu paydaşın, Bilecik turizminin pazarlama çalışmalarını yeterli bulmadığı görülmektedir. Buna karşın ulusal veya uluslararası düzeyde Bilecik turizminin pazarlanmasına yönelik çalışması olan paydaş sayısı yok denecek kadar azdır.

P27: "Yok, bulmuyorum. Ben bir ara Turizm Bakanlığı'na da vekalet ettim. Yani oradaki olay da yani elimizden geldiğince kendimiz yapmaya çalıştı. Ama tabi biz şimdi muhalefetiz. Muhalefette elimizden geldiği kadar iyi olan şeylerin hepsine destek veriyoruz. Arkadaşlarımız da yapabildiklerini yapıyorlar. Ama bunda el birliğinin daha çok olması lazım. Ankara'da ağırlık yapmak lazım. Boş bırakmamak lazım bu konular1."

P2: "Yeterli bulmuyorum. Yani neden yeterli bulmuyorum? Bilecik'te olan şeyi kimse bilmiyor. Bilecik'in değerini kimse bilmiyor. Mermer fuarı yapılır, bütün mermerciler İstanbul, Ankara, İzmir, Konya gibi her yerden geldiler. Dedim ki: "hani, bakın gezmek isterseniz Şeyh Edebali Türbesi var, göletimiz var. Şehir merkezimizi gezebilirsiniz." Yok, dediler. Biz gitmek istemiyoruz."

P1: "Kesinlikle hayır, bulmuyorum. Çünkü ticaret odalarımızda bu tür etkinlikler sadece fuardan fuara bir etkinlik düzenleniyor. İşte Metris Tepe yürüyüşü düzenleniyor yılda bir kez ama ertesi gün unutuluyor. Çok daha etkin bir tanıtım ve reklam faaliyeti gerekmekte."

P7: "Yok, hayır. Yani Bilecik turizmini sadece bir Söğüt Şenlikleri’nde tanıtılıyor. Geri kalan zamanda hiçbir şey yok."

P18: "Yeterli değil. Kendi gücümüzle bir şekilde pazarlamaya çalışıyoruz. Nedir? Yöresel ürünlerimizi öne çıkarmak için fuarlara belediyenin etkin destekleriyle yönlendirmeye uğraşıyoruz. Esnaflarımızı, okullarımızı bu tür destekleyerek, okullarımızı Ankara ve İstanbul'daki fuarlara yönlendiriyoruz. Ama tabi ki bunlarda belli bir yede tıkanıp kalıyoruz. Ama bakanlıkların da Kültür ve Turizm Bakanlığı, Gençlik Spor İl Müdürlügü, Millî Eğitim Bakanlığı, Valiliklerin de İl Özel İdarenin de destekleriyle bu, daha büyük alanlara, belki de yurt dışına açılmamıza da sebep olabilir."

P13: "Yeterli değil. Değil tabi ki. Ümit veren çalışmalar var. Yerel yönetimlerle, il özel idarisiyle, üniversitemizle, sivil toplum kuruluşlarıyla ortak yürütülen projeler var. Bursa, Eskişehir, Bilecik Kalkınma Ajansımızın, BEBKA'mızın desteklediği projeler var. Bunlar birden olmuyor.”

P23: "Yani tabi biz elimizden geleni yapıyoruz. Her sene Emitt Fuarına katılıyoruz. Sonra Antalya'ya da gidildi, ticaret odasıyla birlikte. Tabi yerel ürünlerle ne kadar çok şeye katılabilirsek. Bir de bu hepsi bir bütün arz ediyor. Bunun yanında turizm acentelerinin de bize destek olup, turlar düzenlemesi lazım."

P24: "Gerek resmî kurumların gerekse de özel girişimcilerin ulusal ve uluslararası çapta bu yönde yaptıkları faaliyetler bulunmaktadır. Söz konusu faaliyetlerin geliştirilmesi için ortak akıl toplantıları ve geniş katılımlı toplantılar yapılmaktadır. Üniversitemizin çeşitli birimlerinde de bu yönde gelişmelere destek sağlayabilecek nicelik ve nitelik yönünden zengin faaliyetlerimiz olmaktadır."

P8: "Yeterli bulmuyorum. Yeterli olmuş olsaydı zaten Bilecik'te turizm patlamış olurdu. Patlamadığına göre demek ki yeterli değil herhalde."

P14: "Şu an daha yeni başladığı için daha yeni ölçebiliyoruz. Yani ölçülmeyen bir şeyi çok fazla iyi ya da kötü diye nitelendirmezsiniz. Ama şu an ki bakmış olduğumuz şeyde, tabi burada fuarlara katılım, uluslararası sempozyumlara katılım veya büyük organizasyonların burada yapılması veya buradan oraya gitmesi veya kardeş şehir ilişkileri gibi yapıların artık daha fazla olması Bilecik'in tanınırlığını artırdı. Aslında hani yeni başlıyor; ama şu an yeterli seviyede gidiyor diyelim; ama tabi artırılması lazım.”

P28: "Yok, yeterli değil. Yani şöyle bizim klasik yaptığımız çalışmalarımız var. Yani nedir onlar? Daha ziyade turizm fuarlarına katılım biçimlerinde. Orada turizm il müdürlüğümüzün, valiliğimizin ve belediyemizin hazırladığı kitap, broşür gibi tanıcı görsel materyallerin, yazılı materyallerin fuara gelen, ziyarete gelen misafirlere tanıtılması veyahut verilmesi biçiminde bir şey var. Ama onun dışında açıkçası ulusal bazda yapılan ne var, çok da fazla bir şeyimiz yok."

P4: "Yok, yeterli bulmuyorum. Ben yıllardan beri uğraşıyorum. Ben yıllardan beri uğraşıyorum, tanıtmaya çalışıyorum. Önümüzü kesiyorlar. Önümüzün bizim tanıtmamız için açılması lazım.”

P15: "Kesinlikle yeterli değil, kesinlikle yeterli değil. Yani biz vakıf olarak da hani sürekli yaptığımız çalışmalar var. Ama kesinlikle yeterli değil." 
P5: "Kesinlikle hayır. Bence bunda yerel yöneticilerin, vali olsun, belediye başkanı olsun, ilçelerin belediye başkanları olsun, kaymakamlar olsun, ne yapılabilir düşünmesi gerekir."

P9: "Maalesef, bulmuyorum. Üniversitemiz burada, belediyelerimizin üniversiteyi çalıştırmaması. Çalışırmıyor derken üniversite hazır, üniversitede bunun fazlası var. Üniversite kendiliğinden çalışıyor. Ama biz, yerel yönetimler, belediyelerimiz bundan istifade edemedik, edemiyoruz."

P19: "Biliyorsunuz, Söğüt'te bir şenliğimiz var. Ama bu şenliğimiz benim kanaatimdir, çok fazla da ön plana çıkaramadık. Bu şenliği biraz daha artık turizmi deyimiyle daha güzel pazarlayabilirsek eğer, Bilecik'in bilinirlikle ilgili bir sorunu yoktur diye düşünüyorum.

P20: "Yani şu anda şöyle şöyleyeyim; zaten pazarlanacak durumda değil. Yani mesela ben kendi ilçemden örnek vereyim. Biz istesek TÜRSAB'dan hemen günü birlik turlara başlıyoruz. Ama getirsem, yani şimdi neyi gezdireceğim? Birkaç tane restore edilmiş yerimiz var. Restore edilmekte olan yerler var. Yani böyle çok insanları mutlu edecek bir ortam daha sağlayabilmiș değiliz."

Paydaşların çoğunluğu, Bilecik turizmi için gerçekleştirilen pazarlama çalışmalarını yetersiz bulmaktadır. Bilecik İl Kültür ve Turizm Müdürlüğü ve Bilecik Belediyesi haricinde pazarlama çalışmalarını yeterli bulan paydaş bulunmamaktadır. İlin pazarlanması için etkin bir pazarlama programının yapılmadı̆̆ı görülmektedir. İlin pazarlama çalışmaları fuarlara katılım, ili tanıtmak için broşürlerin hazırlanmasından ibarettir. Paydaşların geneli, bu sorunun çözülmesinde yerel yönetimlere görev düştüğünü belirtmiştir.

\subsubsection{Paydaşların Bilecik İlinin Bir Turizm Destinasyonu Olarak Konumlandırılması Hakkındaki Görüşleri}

Bilecik İlinin bir turizm destinasyonu olarak konumlandırılmasının değerlendirilmesi için paydaşlara yarı yapılandırılmış mülakatlarda "Bilecik ili bir turizm destinasyonu olarak nasıl konumlandırılmalıdır?" sorusu yöneltilmiş̧ir. Mülakatın ikinci teması bu soru yardımı ile oluşturulmuştur. İkinci temanın ana sorusunu destekleyen iki yardımcı soru daha mevcuttur. Bunlar hedef kitle ve ilin benzer destinasyonlarından farklılıklarıdır. Bazı paydaşlara mülakat esnasında konumlandırma kavramı açıklanarak konu basit bir dille anlatılmıştır. Buna göre paydaşların ikinci tema çerçevesinde belirttikleri görüşler aşağıda sıralanmıştır.

P24: "Bilecik'in tarihi ve kültürel dokusu dolayısıyla, Akdeniz ve Ege sahillerini tercih eden turist kitlesinin yanında son yıllarda ivme kazanan doğa, kültür vb. turizmi ağırlıklı bir turizm politikası takip edilmesi hedef odaklı gidilmesi açısından faydalı olacaktır. Şüphesiz her bölge kendi değerlerini ön plana çıkaracaktır ancak tarihi değer ve yapılar değiştirilmeyeceği için Bilecik'in bu yönden vazgeçilmez bir zenginliği bulunmaktadır."

P12: "Bilecik'in günübirlik turizm algısını değiştirmek ve ailece yıllık tatilin geçirilebileceği bir yer olduğu ile ilgili bir anlayışın geliştirilmesi gereklidir. Böylece tarih, inanç, kültür, doğa ve şifa konseptleri çerçevesinde kentte uzun süreli tatil yapılabileceği algısı oluşur."

\section{Bilecik Turizminin Hedef Kitlesi}

Bilecik turizminin daha etkin nasıl pazarlanması gerektiğini paydaşlar açısından değerlendirirken paydaşlara Bilecik turizminin hedef kitlesinin nasıl olması gerektiği sorulmuştur. Paydaşların, Bilecik turizminin hedef kitlesinin nasıl olması gerektiğine dair vermiş olduğu cevaplardan öne çıkanlar aşağıda sıralanmıştır.

P28: "Eğer doğa turizmini hedefliyorsak; eğer alt yapıyı oluşturabilirsek, ben Orta Doğu coğrafyası ve Kuzey Afrika'dan bile buraya çok ciddi bir turist geleceğini düşünüyorum. Temel şey burada alt yapı. Altyap1 oluştuktan sonra buranın hem Avrupa'dan; ama özellikle Orta Doğu coğrafyasından ve Orta Doğu'nun zengin yani Birleşik Arap Emirlikleri, Katar gibi, Suudi Arabistan gibi turizm açısından da bir yerde para olarak da güvenebileceğin bir turizm potansiyelinin olabileceği kanaatindeyim."

P14: "Herhangi bir hedef kitleye odaklanmayalım. Gelen herkesi kabul edelim ya da hepsi gelsin. Çünkü hiçbiri azımsanmayacak kadar fazla. Yani sadece şu kitleye odaklanıp, öbür kitle kendisi ne yaparsa yapsın demek çok uygun olmaz. Çünkü hepsi ayrı noktalarda farklı nüanslarıyla tanıtıyorlar."

P23: "Bence tarihi olarak, kültür ortaklığımızın olduğu ülkelere yönelmek daha mantıklı. Avrupalılar Çanakkale'ye çok ilgi duyuyorlar. Ama oradaki Anzaklardan dolayı o da. Onun dişında buraya o ilgiyi gösterdiklerini sanmıyorum. Özellikle Türk Cumhuriyetleri, Ertuğrul Gazi’yi anma etkinliklerimize sık sık da gelir. Her sene hatta oralardan davetlilerimiz de oluyor. O pazara yönelmemiz daha mantıklı olur."

P25: "Ulusal boyutta bir defa öncelikle herhalde Kültür ve Turizm Bakanlığı'na tanıtmamız lazım, Bilecik diye bir şehrin olduğunu. Uluslararası boyutta ise öncelikle Osmanlı sayesinde vakti zamanında ortak bir geçmişimizin olduğu coğrafyadaki insanlara yönelmek gerekir. Daha çok ilgilenirler diye düşünüyorum. Avrupalının bakış açısı daha farklı bana göre. Türk Cumhuriyetlerine de kesinlikle tanıtım olmalı. Hatta bir 
şekilde onlara ne derler; daha ucuz, daha büyük imkanlar, daha kolay ulaşılabilme imkânı sağlanırsa, onların da buraya teveccüh edeceklerini düşünüyorum açıkçası."

P13: "Bir kere Osmanlı büyük bir kültürdü. Osmanlı coğrafyasının elinin değdiği her yer. Bugün 64 ülke var diye biliyorum. Osmanlının elinin değdiği topraklar olarak, Balkanlarda, Kafkaslarda, Afrika'da, Orta Doğu'da. Bilecik, bu ülkeler için caziptir."

P18: "Türkiye'de bence önce ilkokul öğrencilerine tanıtmamız lazım. İlkokul öğrencileri tanıdıkları zaman yaş ilerledikçe bunun çocuklarına ve büyüklerine daha rahat bu yönde tanıtma imkânı olur. Uluslararası boyutta para yönünden bakarsanız Avrupa. Ama bir Türkiye'deki güç sağlamak olarak düşünürseniz Türk Cumhuriyetleri olarak düşünüyorum.”

P26: "Uluslararası boyutta kimsenin ilgileneceğini düşünmüyorum. Biz yerel turistlere, yerel olarak tanıtım yapmalıyı."

P7: "Bilecik için şu an hedef kitle olabilecek Araplar var. Osmanlıyla alakalı. Çünkü çok büyük bir sempatileri var şu anda. Hem diziler olsun hem işte Türkiye'nin şu anki politik durumundan itibari ve yeşili inanılmaz seven insanlar. Dağı, yeşilliği. Nasıl Bursa'yı çok seviyorlarsa yeşillikli dağlarından dolayı, Bilecik'te de bunu sağlayabilirler."

P1: "Ulusal boyutta hedef kitlemiz bence en yakın civardaki illerin belediyeleri. Belediyeler birer bütçe ayırarak bir miktar ulaşımlarını sağlayarak turlar düzenlemeli. Uluslararası boyutta ise Türk Devletleri iyi bir Pazar. Çünkü nereden esinleniyorum: Eskişehir Türk Kültür Dünyası başkentiydi.

P27: “Bilecik'ten başlamak lazım. Önce Bilecik'e tanıtmak lazım. Ondan sonra Türkiye'nin içerisinde bunu büyüterek burasını bir öne getirip, sonrasında bana göre Avrupa'dan daha çok diğer Türk ülkelerle ve diğerleriyle bu işi götürmemiz lazım."

P19: "Bizim öncelikle hedefimiz iç turizm. Yani Bilecik turizmi olarak ortaya çıktığımızda Osmanlı'nın kurulduğu yer olarak çıkıyoruz. Avrupalının pek Osmanlının kurulduğu yeri merak edeceğini düşünmüyorum. Tabi pazarlamaya bağl1."

P21: "Ulusal boyutta, muhafazakâr, milli ve manevi değerlere önem veren kişilikteki turistler çekilebilir. Uluslararası boyutta ise yine aynı şekilde Orta Doğu."

P15: "En azından Osmanlı İmparatorluğunun idare edildiği coğrafyalar olmalı. Yani ulusal düzeyde zaten bunu yapmamız gerekir. En azından uzun yıllar aynı devlet çatısı altında özellikle Balkanlar, Türk Cumhuriyetleri hedef kitlemiz olmalı."

Paydaşlar Bilecik turizminin hedef kitlesinin Türk Cumhuriyetleri, Orta Doğu ve yerli turistlerin olması gerektiğini ifade etmiştir. Öncelikle hedef kitlesinde Bilecik'in kendi yerel halkını belirleyip, yakındaki belediyelerle iletişime geçilerek yakın şehirlerdeki potansiyel ziyaretçilerin hedeflenmesinin doğru olacağ 1 düşünülmektedir. Orta Doğu'nun Osmanlı İmparatorluğu'nun kuruluş yeri olması sebebi ile Bilecik'e ilgi gösterecekleri ifade edilmiştir. Bununla birlikte Türk Cumhuriyetleri de Bilecik'e ilgi gösterecek ve pazar olarak seçilebilecek hedef kitleler arasında yer almaktadır.

\section{Bilecik Turizminin Benzer Destinasyonlardan Farklılığı ve Rekabet Avantajı}

P25: "Valla farklı kılan çok bariz bir fark turizm açısından düşündüğümüzde. Geri kalmışlı̆̆ımız dışında bir şey yok. Osmanlının doğduğu yer. Ama onu da ancak biraz daha görselliği ön plana çıkarak, biraz daha türbeyle bunu ön plana çıkaramayız yani."

P12: "Benzer destinasyonlara göre konum olarak oldukça avantajlıdır. Bir yanda İstanbul, Eskişehir, Antalya yolu üzerinde iken, diğer yanda Ankara, Bursa, Çanakkale yolu güzergahındadır."

P15: "Bilecik'in benzer destinasyonlardan farklılığı kesinlikle özgün bir tarihe sahip olmasıdır. Başka yerde yok zaten. Rekabet avantaj1 da konumdur. Merkezi bir yer."

P10: "Kültür ve tarihi değeridir. Kuruluşun ve kurtuluşun beşiği olmasıdır. Bugün Bilecik'in nesi meşhur dediğiniz zaman tanıtmak için mermeri meşhur, mermeri var deriz, seramiği var deriz, çanak çömleği var deriz. Yani bu üç ana unsuru söyleyebiliriz yani."

P3: "Bizim benzer destinasyonlardan çok büyük farkımız var. Biz farkında değiliz öncelikle. Bizim elimizde Ertuğrul Gazi var, işte bir Şeyh Edebali Hazretleri ile Dursun Fakih var. Aslında bunlar çok büyük bir değer bizim için. Onlarla değeri biçilmeyecek bir değer."

P20: "Bursa belki Osmanlı'ya başkentliğini yapmış bir yer. Ama Bursa'da öne çıkan onun dışında çok farklı şeyler var. Eskişehir'e bakıyorum. Onlar zaten büyük oranda hocanın (Yılmaz Büyükerşen) yarattı̆g 1 algılarla turist getiriyorlar. Bolu zaten ölü gibi geliyor. İzmit de zaten sanayi kenti. Osmanlı'yı kullanabilecek demek ki tek yer biz kalıyoruz. Bence büyük oranda Osmanlı ile ilgili yani ne geliştirebilirsek, bunlar bizim önümüzü açacak, diğerlerinden farklı kılacaktır." 
P21: "Açıkçası çok bariz bir şekilde diğerlerinden farkı sadece Osmanlı'nın kuruluşu diyebiliriz. Yani tohumların burada atıldığını ön plana çıkartabiliriz."

Paydaşlar, Bilecik turizminin benzer destinasyonlardan farklılığı ve rekabet avantajı konusundaki düşünceleri ilin tarihi önemi ve ilin konumu çevresinde toplandığg görülmektedir. Osmanlı İmparatorluğu'nun Bilecik sınırları içerisinde kurulmuş olması benzer destinasyonlardan farklılık yaratacağ düşünülmektedir. Birçok büyük şehre yakın olmakla birlikte karayolu ve demiryolu ulaşımının da kavşak noktasında yer alması, turizmde rekabet avantajı sağlayacă̆ düşünülmektedir.

\subsubsection{Paydaşların Bilecik İlinin Bir Turizm Destinasyonu Olarak İmajı Hakkındaki Görüşleri}

Bilecik' in bir turizm destinasyonu olarak imajının değerlendirebilmesi için paydaşlara yarı yapılandırılmış mülakatlarda "Bilecik il olarak turistik bir imaja sahip midir?" sorusu yöneltilmiştir. Mülakatın üçüncü teması bu soru yardımı ile oluşturulmuştur. Üçüncü temanın ana sorusunu destekleyen 3 yardımcı soru daha mevcuttur. Bunların nasıl bir imaja sahip olduğu, turistin aklına ne geldiği ve ne gelmesi gerektiği ve ilin imajına olumlu veya olumsuz etki eden durumların ne olduğudur. Bazı paydaşlara mülakat esnasında imaj kavramı açıklanarak konu basit bir dille anlatılmıştır. Buna göre paydaşların üçüncü tema çerçevesinde belirttikleri görüşler aşağıda sıralanmıştır.

P4: "Turistik bir imaja sahibiz. Ancak pazarlayamıoruz. Pazarlamak çok önemli ama pazarlayamıyoruz."

P28: "Çok gönül rahatlığıyla böyle bir imaj var diyemem. Şu anda Bursa' da mesela karşılaştırdığımızda Bursa'nın bir Osmanlı şehri algısı var, halbuki hiç alakası kalmadı."

P23: "Yani net bir imaj yok. Ama yine de haliyle tabi tarih ortaya konulunca mutlaka herkesin ilgisi dahilinde."

P13: "Tam sahip olduğunu söyleyemeyiz."

P7: "Valla Bilecik deyince insanların aklına: 'Ben orada askerlik yaptım bir daha görmek istemiyorum'."

P2: "Aslında sahip olması gerekiyor. Ancak şu an için sahip değil."

P27: "Yeni yeni olmaya başlıyor. Şu an da turistik demiyor belki ama yeni yeni oluşmaya başlıyor."

P20: "Bence çok olmuyor, yani öne çıkartamıyoruz. Bir yolla mesela Bilecik ile özdeştirecek şeyleri ortaya koyabilmeliyiz."

P19: "Hangi açıdan baktığına bağlı tabi. Bilecik dışında sorduğunda bunun cevabı maalesef olumsuz.

$P 21$ : "Yani direk aklımıza geleni söyleyemiyoruz. Bu sebeple turistik bir imaja sahip değildir."

P10: "Turizm geliyor mu yani şimdi. Yok gelmiyor. Turistik bir imaja sahip değiliz."

P16: "Bilecik il olarak turistik bir imaja sahip değil."

P15: "Çok profesyonel bakarsak değil. Ama tarihi geçmişi bir zenginlik oluşturuyor, bir destinasyon diyebiliriz. Ama profesyonel manada bir imaji yok."

P9: "Bilecik deyince insanların aklına ilk tarihi yerlerimiz iyi bir şekilde gelmelidir. Ama imajı yok."

Bilecik İlinin turistik bir imaja sahip olup olmadığı konusunda çoğu paydaş olumsuz değerlendirmede bulunmuştur. Her ne kadar az sayıda paydaş, imajın yavaş yavaş oluştuğunu ifade etmişse de Bilecik'in turistik bir imaja sahip olduğu söylenmemektedir.

\section{Bilecik’in Turistlere Çağrıştırdıkları İle İlgili Düşünceler}

İmaj ile ilgili oluşturulan temanın alt problemlerinden birisi de turiste Bilecik'in ne çağrıştırdığ ve ne çağrıştırması gerektiğidir. Gerçekleştirilen yarı yapılandırılmış mülakatlarda paydaşların Bilecik'in hiçbir şekilde bir imajının olmadığını düşünenler buna paralel olarak turistlerin aklına bir şeyin gelmediğini ifade etmiştir. Bunun haricinde paydaşlar Bilecik'in neyi çağrıştırması gerektiği sorulduğunda ise alınan cevaplar tarih ve Osmanlı çevresinde toplanmaktadır. Bu sebeple yoğun bir şekilde paydaşların, ilin Osmanlı'y1 çağrıştıracak şekilde imajının oluşturulmasını talep ettiği görülmektedir.

\section{Bilecik’in Turistik İmajına Olumlu veya Olumsuz Etki Eden Unsurlar}

Turistik imaja dair oluşturulan temanın alt problemlerinden birisi de turistik imaja etki eden olumlu veya olumsuz unsurlardır. Bu bağlamda paydaşlardan Bilecik'in turistik imajına olumlu veya olumsuz etki eden unsurları değerlendirmeleri istenmiştir. Paydaşların değerlendirmelerinden öne çıkanlar aşağıda sıralanmıştır.

P4: "Pazarlama eksikliğimiz var. Pazarlamadıktan sonra hiç düşünmez adam yani."

P23: "Bilecik'in büyük illerin arasında sıkışmış olması mı, küçük bir il olması mıdır acaba?"

P13: "Yeterince tanıtılmadığı için."

P26: "Bir imaj yaratmaya çalışmıyoruz zaten. Böyle bir çabamız yok. Yapılıyorsa da göstermelik yap1liyor." 
P7: "Tanıtılmaması, bir politikanın ortaya konulmamış olması, turizmin ele alınmıyor olması diye sayabiliriz."

P27: "Çok büyük şehirlerin arasında bir küçük şehir kalmasından dolayı tanıtamıyoruz. İmaj oluşturulamiyor."

P16: "Tanıtım ve altyapı eksiklikleri imaja olumsuz etki yapmaktadır."

P15: "İmaja olumsuz etki eden konu, profesyonel olarak turizmin ele alınmamış olmasıdır."

P12: "İlimiz tarih, doğa ve kültürel miraslar bakımından çok zengin. Fakat ilimizin tanınırlığı yeterli değil. İnsanlar maalesef ilimizi yeterince tanımıorlar."

Paydaşlar, Bilecik'in turistik imajına olumlu ve olumsuz etki eden unsurlara ilişkin değerlendirmelerinde pazarlama eksikliğinden, ilin büyük illerin arasında sıkışmış olmasından, altyapı eksikliğinden ve turizmin profesyonel bir şekilde ele alınmıyor olmasından bahsetmiştir. İlin yeterince tanınmaması ve bununla birlikte verimli tanıtma çalışmalarının olmaması ilin turistik imajına olumsuz etki etmektedir. Bazı durumlarda üstünlük sağlayan konum, turistik imaja olumsuz etki ettiği görülmektedir. Paydaşlar, ilin turistik imajına etki eden olumlu bir unsurdan bahsetmemektedir.

\subsubsection{Paydaşların Bilecik İlinin Bir Turizm Destinasyonu Olarak Markalanması Hakkındaki Görüşleri}

Bilecik İlinin bir turizm destinasyonu olarak markasının değerlendirebilmesi için paydaşlara yarı yapılandırılmış mülakatlarda "Bilecik ili bir turizm destinasyonu olarak markası var mıdır?" sorusu yöneltilmiştir. Mülakatın dördüncü teması bu soru yardımı ile oluşturulmuştur. Dördüncü temanın ana sorusunu destekleyen 3 yardımcı soru daha mevcuttur. Bunlar ili bir turizm destinasyonu olarak markalama çalışmasında ilin sloganın, ilin logo ve sembolünün nasıl olması gerektiği ile şehrin marka şehir olabilecek altyapı ve üstyapıya sahip olup olmadığıdır. Bazı paydaşlara mülakat esnasında marka kavramı açıklanarak konu basit bir dille anlatılmıştır. Buna göre paydaşların dördüncü tema çerçevesinde belirttikleri görüşler aşağıda sıralanmıştır.

P4: "Bilecik' in turizm destinasyonu olarak markas1 yok. Böyle hani Bilecik turizmin merkezi falan filan denilmiyor."

P28: "Yani marka olarak yakın zamanda arkadaşlarımız, belediye başkanı arkadaşlarımız birtakım çalışmalar yaptılar. Ama açık söyleyeyim, mesela bizdeki marka dediğimiz zaman neyi anlamamız lazım? İşte diyelim ki Konya'da Mevlâna Türbesi bir markadır, hakikaten. Konya direk akla geliyor. Erzurum dediğimiz zaman oradaki neydi o medrese var, ondan sonda Edirne'de cami, cami bir marka. Bursa dediğiniz zaman Yeşil Türbe veya Ulu Cami akla geliyor. Ama Bilecik dediğimiz zaman bilen için tırnak içinde söylüyorum bir Ertuğrul Gazi ve Şey Edebali'den başka da açıkçası şu anda Bilecik'i markalaştıracak turizm anlamında bir şeyimiz yok maalesef."

P14: "Markası derken logosu gibi bir şeyden bahsediyorsanız eğer, şu an çalışmaları var. Şimdi biz de markalaşma adına Ertuğrul şehri şeklinde burayı markalayacak çalışmalar yapıyoruz."

P23: "Burada Kuruluş ve Kurtuluşun Beşiği dışında ön plana çıkarabileceğimiz bir şey yok. Bir marka olmak için hakikaten bir şeyi koymamız lazım ki o çıksın meydana."

P13: "Mutlak olduğunu düşünüyorum. Yani tek bir isimle de değil yani kişilerin ilgisine göre farklı farklı markalarda da ortaya çıkabilir. Yani bugün Türkiye'nin en zorlu rafting alanlarından veya kanyon alanlarından bir tanesi diye Harman Kaya kanyonumuz bir marka olur. Ama belki sizin için benim için olmaz."

P26: "Hayır, imajı yoksa zaten markası da olamaz. Bu sebeple Bilecik' in turizm destinasyonu olarak bence markas1 yok."

P7: "Bilecik'in şu anda tek markası bej mermer, başka bir şe yok. Bu sebeple turizm açısından da Bilecik marka bir şehir değil. Markası yok."

P27: "Diğer marka şehirlerin yanında yok. Yani bizim açımızdan var da ama incelendiğinde dünyaya baktığında yok yani. Türkiye'nin o kadar çok önemli yerleri var ki bir tanesi Bursa misal, bir tanesi Mevlana'nın olduğu yer Konya. Ama bunlar kadar Bilecik de önemli. Hani biz biraz geri kalmışız.”

P3: "Bilecik' in bir imaj1 yok, doğal olarak bir markamız da yok bana göre zaten."

P20: "Bilecik'in tabi marka olduğuna inanmıyorum; ama mesela işte bir ürettiği ürünler anlamında, bu konuyla tam ilgisi olması sebebiyle bizde çok moda var ya arada toplanıyor işte marka şehir Bilecik falan işte markalarını yaratmak. Önceden var olan markaları var, ama turizm anlamında söylemiyorum.”

P22: "Marka çalışmakla ve insanların kabul etmesiyle olur. Yani şimdi markası olduğunu söyleyemeyiz. Birdenbire olmaz. Yani emek vermemiz lazım. Biz ama daha çok yolun başındayız marka konusunda." 
P16: "Şu anda markası yok. Yapılmaya çalışılıyor. Ama tabi bunu mermeriyle mi markalaştıralım, toprağıyla mı markalaştıralım, ipek böcekçiliğiyle mi markalaştıralım, şerbetçi otuyla mı markalaştıralım, bunların hepsi ürün bazında. Bu arada çok büyük bir değer var: tarih turizmi.”

P6: "Bir kere tanıtmadan markalayamazsınız. Önce diyeceksin ki Bilecik'te şu var, bu var. Ondan sonra ön plana ne çıkacaksa onun üzerine yoğunlaşacaksın."

P9: "Marka değil. Marka olma şartı şu; kurulduğu yerde Osmanlının kuruluşunu canlandırırsan ancak insanlar aklına kazır."

Paydaşlar, Bilecik'in bir turizm destinasyonu olarak markası olmadığını düşünmektedir. Ayrıca paydaşlar, imajı olmayan bir destinasyonun markasının da olmayacağı düşüncesindedir. Bazı paydaşlar, Bilecik'in yöresel ürünlerinden markalaşan ürünlerin olduğundan bahsetmektedir. Bilecik bej mermeri, narı, ayvası, bozası, şerbetçi otu önce gelen ve Bilecik ile anılan yöresel ürünlerdir. Ancak bu ürünler, Bilecik'in bir turizm destinasyonu olarak markalaşmasına yeterli olmadığı düşünülmektedir. Paydaşlar, Bilecik'in markalaşma konusunda yolun daha çok başında olduğunu ve daha fazla çalışılması gerektiğini belirtmektedir.

\section{Bilecik'in Turizm Destinasyonu Olarak Sloganı}

Bilecik için halihazırda kullanılan slogan ‘Kuruluş ve Kurtuluşun Beşiği Bilecik’tir. Dördüncü temanın alt problemlerinden birisi de markalamada önem kazanan sloganın Bilecik için nasıl olması gerektiğidir. $\mathrm{Bu}$ sebeple yarı yapılandırılmış mülakatlarda paydaşların mevcut sloganı değerlendirmeleri ve alternatif fikirleri varsa belirtmeleri istenmiştir. Paydaşların görüşleri aşağıda sıralanmıştır.

P4: "Bilecik'e sloganı tarihsel bir slogan bulmak lazım. Tarih olarak bir slogan bulup, bunu Türkiye'ye lanse etmek lazım. Şimdiki slogan uygundur."

P28: "Yani kuruluşun ve kurtuluşun beşiği Bilecik bizim çok sık kullandığımız ve aslında sahip olduğumuz değerleri hatırlatma anlamında iyi bir slogan. Bence başarılı mevcudiyeti babında. Ama bence bir farkındalık oluşturmak lazım burada. O farkındalığı oluşturacak birden fazla slogan üstünde çalışmamız gerekiyor."

P14: "Yeni bir arayış içine girilmesi lazım. Çünkü artık yani bu zamana kadar zaten kullanılan bir şey halen markalaşmadıysa orada bir sıkıntı var demektir. Tekrar yeni bir şeyin üretilip, onun markalaşması belki onun daha çok büyümesine sebebiyet verecektir ki biz dediğimiz gibi öz kaynaklara kat ve kar sahibiz."

P23: "Kuruluş ve Kurtuluşun Şehir Bilecik; valla bu mantıklı güzel geliyor bana; ama onun dışında başka bir şey de geliştirebiliriz."

P18: "Bence sloganları turizm türlerine çeşitlendirmek gerekiyor. Hani Osmanlı için ayrı bir slogan oluşturmamız lazım. Çünkü tarih isteyenler ayrı. Doğa turizmi için ayrı bir slogan, spor için ayrı bir slogan olarak oluşturup, her kesimi burada birleştirmemiz gerekiyor."

P26: "Mevcut sloganı yeterli bulmuyorum. Akılda kalabilecek, daha etkileyici bir slogan olmalı."

P7: "Akılda kalan bir slogan değil"

P1: "Şu anki slogan uygun. Ancak yenilenecekse de ben yine Osmanlı İmparatorluğu'nun kuruluşu ile ilgili bir slogan olsun diyorum."

P27: "Bu profesyonel bir çalışmayla tasarlanmalı. Şimdiki kuruluş ve kurtuluşun beşiği de tutuyor yani. Bilecik' in taşı, ipeği, işte mermeri hepimizin söylediği sözler. Ama daha iyisi, daha çekicisi ki bu bir yaratıcılık yani böyle bir şeyi de olabilir."

P3: "Tarihi slogan ile pazarlama olmuyor. Kuruluş ve kurtuluştan bahsediyoruz ama Ertuğrul Gazi'nin direkt adı geçmiyor ki. Değiştirmek gerekiyor artık kuruluş ve kurtuluşun beşiği sloganını."

P20: "Valla Osmanlı ile özdeşleşecek bir şey olmalı bence. O anlamda çalışmaya ben şu olsun ya da bu olsun diyebilecek kişi değilim. Kendi ilçem için bile onu yapamıyorum."

P19: "Bilecik' in hali hazırda bir sloganı zaten var. Yeterlidir, yetersizdir o noktada farklı görüşler olabilir. Bence güzel bir slogandır. Bu sloganın bilinirliği hem Bilecik ölçeğinde hem de ulusal ölçekte arttırmamız gerekir."

P21: "Geçmişin ve tarihin izlerini yansıtacak şekilde veyahut geçmişten günümüze birçok anonim bir sloganıdır. Ama tarihin derinliklerinden veya tarihimizin başladığı yer veyahut.

P15: "Biz bir 'Kuruluş ve Kurtuluşun Beşiği' sloganını kullanıyorduk daha önce. Şimdi 'Where The Legend is Begin' (Efsanenin Başladığı Yer) sloganını da kullanmaya başladık. Efsaneyi inceleyenler başladığı yeri de merak ederler diye bu ilgiyi uyandırmak lazım.

P6: "Yani düşünmek lazım. Öncelerden taşı mermer, yaprăğ ipek, işte toprağı sanat sloganı vardı. Ancak yeterli değil tabi yani bu slogan."

P9: Kuruluşun başkenti. Kesinlikle sloganımız bu olmalı. Burası cihan devletinin kurulduğu yer, başka ne olabilir?" 
Paydaşlar, Bilecik'in sloganı için farklı görüşler belirtmektedir. Bir kısım paydaş halihazırda kullanılan "Kuruluş ve Kurtuluşun Beşiği" sloganını yeterli bulurken bir kısım paydaş ise yeni ve farkındalık yaratacak sloganın bulunması gerektiğini düşünmektedir. Mevcut sloganı yeterli bulan paydaşlar, sloganın ulusal ve uluslararası boyutta bilinirliğinin artırılmasının gerektiğinden bahsetmektedir. Mevcut slogandan memnun olan paydaşların da yeni sloganın bulunması gerektiğini düşünen paydaşlarında ortak noktası, sloganın ilin tarihine atıf yapması gerektiğini düşünmeleridir. Tüm bunların yanında bazı paydaşlar birden fazla sloganın kullanılmasının uygun olduğunu düşünmektedir. Özellikle tarih turizmi harici geliştirilecek her bir alternatif turizm çeşidi için alternatif sloganların bulunmasının fayda sağlayacağı belirtilmiştir.

\section{Bilecik'in Turizm Destinasyonu Olarak Logo ve Sembolï}

Dördüncü temanın alt problemlerinden birisi de markalama çalışmalarının bir parçası olan logonun, Bilecik için nasıl olması gerektiğidir. Bu sebeple yarı yapılandırılmış mülakatlarda paydaşların mevcut turizm logosunu değerlendirmeleri ve alternatif fikirleri varsa belirtmeleri istenmiştir. Bununla birlikte şehrin sembolünün ne olabileceği konusunda da paydaşların görüşlerine başvurulmuştur. Paydaşların görüşleri aşağıda sıralanmıştır.

P4: "Hiç ilgisi yok Bilecik ile. Saat kulesinin ne alakası var. Bence logo olarak Osmanlı İmparatorluğunun armas1 olabilir. Sembol olarak Söğüt'e odaklanmalıyız. Ertuğrul Gazi silueti olabilir sembol.”

P28: "Şimdi logoyu nerede kullanacağınız çok önemli. Genelde acaba tek logo mu olması lazım yoksa birkaç özelliği birden mi ön plana çıkartacağız? Daha küçük materyallerde oldukça yalın, basit figürlerle yapılması lazım. Ama biraz daha büyük mekanlarda birkaç şey birden üzerine yüklenebilir. Bence kültürel miras anlamında ben Ertuğrul Gazi Türbesini sembol olmasını tercih ederim.”

P14: "Yani saat kulesi, Metris Tepe ve 400 çadırla gelen Osmanlı algısı. Bu da çalışmayı simgeliyor gibi. Gayet uygun bizce. Türbenin simgelenmesini uygun bulmuyoruz biz aslında. Şu an Osmanlı armasını sahiplenmiş durumdayı."”

P23: "Genelde Osmanlı çınarı ön plana çıkarmak lazım, çınar yaprağını. Ben çınar ağacı olmasının mantıklı olacağını düşünüyorum. Şehrin sembolü ise Şeyh Edebali'dir."

P25: "Mevcut logo kalabalık. İnsanlara logo dediğinizde akılda kalan figür olur. Bir defa düşündüğüm zaman ya Metris Tepe olacak ya saat kulesi olabilir ya da Osmanlının otağı olabilir."

P13: "Saat kulesi kullanılmış, bir iki sanayiyi işaret eden çark görünümünde olan hususlar kullanılmış, ama logo illa bunların hepsini birden içermesi gerekiyor mu? Yani bakıldığında bu Bilecik'ten denilecek bir logonun varlığına da ihtiyaç var. Osmanlı kültürel mirasının sembolüyle markalama yapılmalı. Ertuğrul Gazimizin türbesinden tutun, son Osmanlı döneminin sembolleri gibi saat kulesi, rüştiye, idadi gibi binalar Bilecik'i sembolize edebilir."

P18: "Düşündüğüm zaman bir Osmanlıyla bir Metris Tepe İnönü Savaşıla bir ikisinin ortak bir şey birleştirmek isterdim. Yani eskiyle yeniyi modernize etmek isterdim. Sembol için de Ertuğrul Gazi, Osmanlının kuruluşunu, Metris Tepe kurtuluşun savaşının kazanıldığı yer diyebilirim. Her ikisinin de ayrı yeri var.

P26: "Sloganı gibi aynı, aklıda kalmaz zaten fazla bir şey yaparsak. Ama Metris Tepe olabilir. Sembol olarak Metris Tepe olabilir diyorum."

P7: "Şu anki logoyu çok canlandıramıyorum. Yani hiçbir oluşum yok şu anda kafamda. Sembol türbe olmalı kesinlikle."

P1: "Tek bir şey olursa hani ön plana çıkarırız. Yine Osmanlı diyeceğiz o zaman. Sembol olarak bence Metris Tepe kullanilmalı."

P2: "Logo çok kalabalık. Azaltmak lazım simgeleri. Sadece saat kulesi ya da Metris Tepe olabilir. Sembol olarak Şeyh Edebali Türbesi ya da farklı olarak Bozcaarmut Göleti olabilir."

P5: "Bu logo çok kalabalık. Yalnızca Metris Tepe olabilir. Logo için Metris Tepe derim ben. Hatta şehrin sembolü için de Metris Tepe gayet uygun."

P27: "Bu tartışılması gereken bir konu. Hemen karar verilmez. Ama Osmanlı Arması olmaz. Çünkü çok genel. Sembol olarak ise Şeyh Edebali ve Ertuğrul Gazi Türbeleri olabilir.”

P3: "Karmakarışık bir logo olmuş bu. Bizim aslında çok güzel bir logomuz var. Osmanlı Arması. Ama sahip çıkamadık. Sembol olarak Ertuğrul Gazi olabilir kuşkusuz."

P20: "Bence kesinlikle Osmanlı İmparatorluğunun en üst sinırlara sahip olduğu haritanın nasıl simgeleştirilecekse öyle bir logosu olması lazım, onun içeren bir logo anlamında olmalı. Sembol bence Şeyh Edebali Hazretlerinden yola çıkılacak bir şey olabilir yani." 
P19: "Şu anda kalabalık olması gerçekten akılda kalıcılı̆̆ı önlüyor. Anlatacak çok şeyiniz olduğu zaman hepsine anlatmaya gayretine ve pazarlama gayretine giriyorsunuz. Belki bundan kaynaklanabilir sorun. Bilecik'in sembolü de işte n güçlü yanımız, Osmanlı, Söğüt, Şeyh Edebali.”

P21: "Tek bir simgenin olmas1 yeterlidir. Benim sadece gözümün önüne bir Bilecik'teki saat kulesi geldi. Osmanlı sembolü üzerinden gidebilir belki, arması üzerinden gidebilir."

P8: "Çok fazla şey var bunda. Yani şimdi bence Metris Tepe, saat kulesi ve Osmanlı arması olabilir logo. Bilecik'in sembolü en güzel Çınar olabilir."

P6: "Çok kalabalık gerçekten. Bir tane otağ yaparsın, yani ona benzer. Belki öyle bir logo olabilir; ama Osmanlıya da çok bağlı kalmamak lazım. Metris Tepe güzel bir sembol olabilir."

Paydaşlar, logo ve sembol konusunda farklı fikirler öne sürmektedir. Mevcut turizm logosunu çok kalabalık bulmakla beraber akılda kalıcı olmadığını düşünmektedir. Birçok paydaş, logonun Osmanlı’ya atık yapması gerektiğini düşünmektedir. Osmanlı arması, çınar ağacı, il merkezinde bulunan saat kulesi veya Osmanlı otağı, paydaşların düşündükleri logoda kullanılabilecek sembollerdir. Birçok paydaş, ilin sembolü olarak Ertuğrul Gazi Türbesi ve Şeyh Edebali Türbesini ifade ederken buna karşın az sayıda paydaş, türbelerin logo ve sembol olarak kullanılmasının doğru olmadığını düşündüklerini ifade etmektedir. Bozüyük ilçe sınırları içinde yer alan ve kurtuluşu simgeleyen Metris Tepe Anıtı, özellikle Bozüyük’teki paydaşlar tarafından ilin sembolü olarak düşünülmektedir. Farklı olarak Pazaryeri ilçesinde bulunan Bozcaarmut Göleti ilin sembolü olabilecekler arasinda ifade edilmektedir.

\section{Bilecik'in Markalaşabilmesi için Altyapı ve Üstyapının Değerlendirilmesi}

Paydaşlar ile gerçekleștirilen yarı yapılandırılmış mülakatlarda paydaşların, Bilecik'in markalaşabilmesi için altyapı ve üstyapısının değerlendirmesi istenmiştir. Dördüncü temanın alt problemi olan bu konuda paydaşlara "Bilecik, turizm taleplerini karşılamak için yeterli altyapı ve üstyapıya sahip midir?" sorusu yöneltilmiştir. Sorunun anlaşılması için paydaşlara altyapı ve üstyapı kavramları açıklanmıştır. Mülakat gerçekleştirdiğimiz her bir paydaş Bilecik' in turizm talebini karşılayabilmek için altyapı ve üstyapının yetersiz olduğunu düşünmektedir. Özellikle üstyapı konusunda çok yol alınması gerektiği dile getirmektedir. Bu sebeple Bilecik'in markalaşabilmesinin önünde büyük bir engel olarak altyap1 ve üstyap1 eksikliği görülmektedir.

\section{SONUÇ VE ÖNERILER}

Destinasyon pazarlaması kapsamında Bilecik turizminin paydaşlar tarafından değerlendirmesi amacıyla yapılan çalışma sonucunda paydaşların, Bilecik turizminin pazarlama çalışmalarını yeterli bulmamaktadır. Kimi paydaşlar bir pazarlama çalışmasının olmadığını düşünürken kimi paydaşlar ise bu çabaların kâğıt üstünde kaldığını ve uygulamaya geçirilemediğini düşünmektedir. Buna karşın birçok paydaşın Bilecik turizminin pazarlaması adına ulusal ya da uluslararası boyutta bir çalışmasının olmadığı gözlenmektedir. Ülkenin birçok bölgesinde görülen "taşın altına el koymama" sorunu, Bilecik ilinde de görülmektedir. Bilecik turizminin pazarlama çalışmalarını yeterli bulmayan paydaşların, bu yetersizliği ortadan kaldırmak için herhangi bir çalışmaları ya da çabaları yoktur. Az sayıda paydaşın ulusal boyutta turizme yönelik çalışmaları mevcuttur. Bunlar da ya klasik tanıtım çalışmaları ya da henüz mutlak amacına ulaşamamış çalışmalardır. Bu durum paydaşların Bilecik turizminin pazarlama çalışmalarının yetersiz olduğuna dair tespitini doğrulamaktadır. Ayrıca Bilecik turizminin etkin pazarlanması önünde de engel oluşturmaktadır.

Bilecik'i benzer destinasyonlardan ayırmak için başarılı bir destinasyon konumlandırmasının yapılması gerekmektedir. $\mathrm{Bu}$ bağlamda paydaşların, Bilecik turizminin hedef kitlesinin nasıl olması gerektiği konusundaki fikirleri önem arz etmektedir. Paydaşlar, Bilecik turizminin Orta Asya Türk Devletlerine, Orta Doğu Ülkelerine ve yerli turistlere pazarlanmasının doğru olacağını düşünmektedir. Tarihsel ve kültürel ortaklığımızın olduğu Orta Asya Türk Devletleri ile vakti zamanında Osmanlı İmparatorluğu'nun hükmettiği Orta Doğu Ülkelerinin Bilecik'e ilgi göstereceği düşünülmektedir. Avrupalı turistin Bilecik'e duyarsız kalacağından dolayı hedef kitle olarak kabul edilemeyeceğini belirtmektedir.

Bilecik'in kendi halkının ili tanımadığı ve bu sebeple iç turizm yönelik pazarlanmanın da Bilecik'in yerel halkından başlanmasının faydalı olacağı düşünülmektedir. Daha çok yetişkin ve 3. yaş turistin, Bilecik'e ilgi göstereceğini düşünen paydaşlar, hedef kitlenin iç turizmde yakın komşu şehirlerin olması gerektiğini düşünmektedir. Paydaşlar, Bilecik turizminin benzer destinasyonlardan farklı ya da Bilecik'e rekabet avantaj1 sağlayacak unsurları ilin tarihi ve konumu olarak değerlendirmektedir. Bilecik turizminin güçlü yanı olan ilin tarihi önemi ve konumu, benzer destinasyonlardan farklı yön olarak rekabet avantajı yaratacak ilin özellikler arasında yer almaktadır. 
Paydaşlar, Bilecik'in turistik bir imaja sahip olmadığını düşünmektedir. Çok az sayıda paydaş ilin turistik imaja sahip olduğunu düşünmektedir. Az sayıda paydaşın düşüncesine göre Bilecik, turistlere Osmanlı'y1 çağrıştırmaktadır. Bununla beraber Bilecik turizmi için sessiz, sakin, güvenilir ve kolay ulaşılabilir çağrışımlarının da olduğu düşünülmektedir. Bilecik'in turistik imajının oluşmama sebeplerini ise paydaşlar dört başlıkla açıklamaktadır. Turistik imajın oluşmama nedenleri pazarlama eksikliği, büyük illerin arasında sıkışıp kalma, altyapı ve üstyapı eksikliği ile turizmin profesyonel olarak ele alınmamış olmasıdır. Paydaşlar, Bilecik denildiğinde ilin turiste tarih ve Osmanlı'yı çağrıştırması gerektiğini düşünmektedir. Bu sebepten dolayı ilin turistin imajıyla ilgili gerçekleştirilecek çalışmalarda bu çağrışımlara odaklanmanın doğru olduğunu düşünmektedir. Çünkü Bilecik'e gelen turistlerin Osmanlı için geldiği düşünülmektedir. Bilecik turizmi için daha etkin bir destinasyon pazarlaması gerçekleştirmek adına turistik imajın oluşmamasına neden olan olumsuz unsurları çözüme kavuşturmak gerekmektedir. Olumsuz unsurların ortadan kalkması ile etkin bir destinasyon pazarlamasının gerçekleştirilebileceği düşünülmektedir.

Paydaşlar açısından Bilecik, turizm destinasyonu olarak bir markaya sahip değildir. Bilecik turizmimin markalaşmamış olduğu düşünülmektedir. Bunun sebebini ise Bilecik turizminin henüz benzer destinasyonlardan farklılaşmadığı, destinasyon konumlandırmasının yapılmadığg ile turistik bir imaja sahip olmadığından şeklinde açıklanmaktadır. Bilecik'in markalaşma adına sadece yöresel ürünlerin olduğunu ancak bunların da dolaylı şekilde turizme katkı yaptığını düşünmektedirler. Bilecik'in markalaşabilmesi için ilin turizm logosunun, sembol ve sloganının profesyonel bir şekilde yeniden değerlendirilmesi gerektiği düşünülmektedir. Bilecik'in turizm sloganının kesinlikle tarihi yansıtmasının, farkındalık yaratacak bir sloganın ile her turizm çeşidi için farklı sloganların bulunmasının ve mevcut slogan kullanılacaksa da ulusal ve uluslararası düzeyde bilinirliğinin arttırılması gerektiğini düşünmektedirler. Mevcut logo, birçok paydaş tarafından kalabalık ve alakasız bulunmaktadır. Daha sade ve tarihe atıf yapan bir logo kullanmanın daha etkin bir destinasyon pazarlaması gerçekleşmesine yardımcı olacağı düşünülmektedir. Paydaşların logoda çınar ağacının kullanılması, Osmanlı Armasının kullanılması, Osmanlı otağının veya saat kulesi kullanılması gibi düşünceleri mevcuttur.

Bilecik turizminin sembolü olabilecek kültürel miraslar arasından Ertuğrul Gazi Türbesi ön plana çıkmaktadır. Ertuğrul Gazi Türbesi'nden sonra sıklıkla paydaşlar, Şeyh Edebali ve Metris Tepe Anıtı'ndan bahsetmektedir. Ancak bazı paydaşlar, türbenin bir pazarlama aracı olarak kullanılmasının doğru olmadığını düşünmektedir. Yakın zamanda Bilecik' in adının Ertuğrul olarak değiştirilmesi gündeme gelmiştir. Bu sebeple Bilecik'in sembolü Ertuğrul Gazi'nin silueti olarak tasarlamak etkin bir destinasyon pazarlaması için doğru hamle olacaktır.

Bilecik turizminin paydaşlar açısından destinasyon pazarlaması çerçevesinde incelendiği bu çalışma sonucunda, çeşitli öneriler getirmek mümkündür. Söz konusu öneriler "Kamu Kurum ve Kuruluşlarına Öneriler, Turizm Sektörüne Öneriler ve Sonraki Araştırmacılara Öneriler” şeklinde gruplandırılmıştır.

\section{Kamu Kurum ve Kuruluşlarına Öneriler}

- Çevre illerde Bilecik'i tanıtmak için turizm ofisleri kurulmalıdır.

- Bilecik tarih destinasyonu olarak pazarlanacaksa ilin fiziksel kanitları buna göre tasarlanmalı ve yenilenmelidir (levhalar, banklar, parklar, aydınlatma vs.).

- Ulusal ve uluslararası fuarlara farkındalık yaratacak şekilde katılım gösterilmelidir.

- Kardeş şehir, kardeş belediye uygulamaları, Bilecik turizminin pazarlanmasında bir araç olarak kullanilmalıdir.

- Bilecik'te yer alan her bir kültürel mirasların çevre düzenlemesi ve aydınlatılmasının yapılarak görselliğinin güçlendirilmesi gerekmektedir.

- Turizm işletmelerine finansal destek sağlayacak kurum ve kuruluşların, bu işletmelere pozitif ayrımcılık yapması gerekmektedir.

- Illgili kurumlar bünyesinde etkin çalışacak turizm komisyonları kurulmalıdır.

- Bilecik turizmini en iyi şekilde yansitacak logo ve slogan için turizm sektörü ile ortaklaşa "logo ce slogan" yarışması düzenlenebilir.

\section{Turizm Sektörüne Öneriler}

- Yeni konaklama tesisleri ve turizme yönelik üstyapı eksiklikleri ivedi şekilde tamamlanmalıdır.

- Bilecik sınırları içindeki her bir doğal kaynak, kültürel ve tarihi değere aynı önem verilip, tanıtım çalışmalarında yer verilmelidir. 
- Ertuğrul Gazi’yi Anma ve Söğüt Şenlikleri tüm paydaşların katılacağı bir toplantıyla yeniden ele alınmalı, şenlikler siyasetin gölgesinden kurtarılmalı ve katılımc1 bir planlama gerçekleştirilmelidir.

- İl merkezi ve ilçelerde gerçekleşen festival ve şenliklerde diğer ilçe şenliklerinin reklamı yapılarak, her etkinliğe katılım sayısı ve etkinliklerin bilinirliğinin arttırılması sağlanmalıdır.

- Bilecik turizminin etkin pazarlanabilmesi için "Destinasyon Yönetim Organizasyonu" kurulmalidir.

- Orta Asya Türk Devletleri, Orta Doğu ve iç turizme yönelik pazarlama planları yapılmalıdır.

- Seçilen hedef kitleye göre Bilecik'in benzer destinasyonlardan farklılığı ortaya çıkartılmalıdır.

- Hedef kitle olarak seçilen ülke ve bölgelerin dillerinde tanıtım broşürleri hazırlanmalıdır.

- Diğer illerde bulunan Bileciklilerin kurmuş olduğu sivil toplum kuruluşlarına ulaşılmalı ve bu kuruluşlar bir pazarlama aracı olarak kullanılmalıdır.

- Seçilen hedef kitlenin gereksinim ve beklentileri tespit edilmelidir.

- Bilecik'in turistlerin zihninde doğru imgeleşmesi için imaj çalışmaları yapılmalıdır.

- Bilecik turizminin etkin pazarlanması için marka kimliği oluşturulmalıdır.

- Bilecik turizmi için farkındalık yaratacak bir slogan bulunmalıdır.

- Bilecik'te gerçekleştirilen ve geliştirilecek her turizm çeşidi için ayrı bir slogan bulunmalıdır.

- Ertuğrul Gazi’nin silueti şehrin sembolü olarak kullanılabilir.

- İmaja olumsuz etki eden unsurlar ortadan kaldırılmalıdır.

- Bilecik turizmi logosunun tarihe atıf yapacak ve farkındalık yaratacak şekilde yenilenmesi gerekmektedir.

- Bilecik turizminin pazarlanmasında sosyal medya kullanımına başlanmalıdır.

- Bilecik turizmi için akıllı telefonlara uygulama yapılmalıdır.

- İlde okuyan turizm öğrencileri etkin bir şekilde kullanılmalıdır.

- Turizm örgütlenmesinde her katılımcı siyasi görüşünden, kimliğinden ve mikro milliyetçi tavrından arınarak elini taşın altına koymalıdır.

\section{Yeni Araştırmacılara Öneriler}

- Bilecik turizmi hakkında daha çok araştırma yapılması sağlanmalıdır.

- Bu çalışmanın görüşmeleri 2015 yılında gerçekleştirilmiştir. Paydaşlar ile yeniden mülakatlar yapılarak yıllar arasında bir kıyaslama gerçekleştirilebilir.

- Devlet Planlama Teşkilatı, Avrupa Birliği veya Kalkınma Ajanslarının yürütmüş olduğu projelere destinasyon pazarlaması konusunda projeler ile katılım sağlanmalıdır.

- Bilecik turizmine etki eden olumlu ve olumsuz tüm faktörlerin tespit edilmesi gerekmektedir.

- Destinasyon pazarlaması kapsamında Bilecik turizmini turistlerin bakış açısıyla değerlendirecek çalışmaların yapılması gerekmektedir.

- Destinasyon pazarlaması kapsamında, diğer iller için de benzer çalışmalar yapılabilir. 


\section{KAYNAKÇA}

Aaker, A. D. and Keller, K. L. (1990). “Consumer Evaluations of Brand Extensions”, Journal of Marketing, Vol: 54, p. 27-41

Aktaş, G. (2007). Turizmde Destinasyon Pazarlaması, Genel Turizm - Turizmde Temel Kavramlar ve İlkeler, Ed: Orhan İçöz, Turhan Kitabevi: Ankara

Arslan, K. (2008). Türkiye'de Kongre Turizminin Geliştirme İmkanları, İstanbul Ticaret Odası, Entegre Matbaacılık: İstanbul

Baker, M. J. and Cameron, E. (2008). “Critival Success Factors In Destination”, Tourism and Hospitality Research, Vol: 26, No: 4 , p. $868-897$

Bardakoğlu, Ö. (2011). "Turistik Ürün Bakımından Destinasyonu Planlaması ve Pazarlaması Kapsamında İzmir Turizminin Değerlendirilmesi ve Geliştirilmesine Yönelik Bir Model Çalışması”, Yayımlanmamış Doktora Tezi, Dokuz Eylül Üniversitesi, Sosyal Bilimler Enstitüsü, İzmir, s. 87

Brooksbank, R. (1994). “The Anatomy of Marketing Positioning Strategy”, Marketing Intelligence \& Planning, Vol: 12, Issue: 4 , p. 10-14

Buhalis, D. (2000). "Marketing The Competitive Destination of The Future", Tourism Management, Vol: 21, p. 97 -116

Caldwell, N. and Freire, J. R. (2004). "The Differences Between Branding A Country, A Region And A City: Applying The Brand Box Model", Journal of Brand Management, Vol: 12, No: 1, p. 50- 61

Ceylan, S. (2011). "Destinasyon Marka İmajı ve Pamukkale Yöresinde Bir Uygulama", Uluslararası İktisadi ve İdari İncelemeler Dergisi, C: 3, S: 7, s. 89-102

Chen, C. F. and Tsai, D. (2007). "How Destination Image and Evaluative Factors Affect Behavioral Intentions?", Tourism Management, Vol: 28, No: 4, p. 1115-1122

Crompton, J. L., Fakeye, P. C. ve Lue, C. C. (1992). "Positioning: The Example of the Lower Rio Grande Valley in the Winter Long Stay Destination Market", Journal of Travel Research, Vol: 31, Issue: 2, p. 20-26

Dacko, G. S. (2008). The Advanced Dictionary of Marketing Putting Theory To Use, Oxford University Pres: UK

Duman, T. ve Öztürk, A. B. (2005). "Yerli Turistlerin Mersin Kız Kalesi Destinasyonu ve Tekrar Ziyaret Niyetleri İle İlgili Algılamaları Üzerine Bir Araştırma", Anatolia: Turizm Araştırmaları Dergisi, C: 6, S: 1, s. 9-23

Echtner, C. M. and Ritchie, J. R. B. (2003). "The Meaning and Measurement of Destination Image", The Journal of Tourism Studies, Vol: 14, No: 1, p. 41

Ersun, N. ve Arslan, K. (2009). "Kongre Turizminin Geliştirilmesinde Kongre ve Ziyaretçi Bürolarının Rolü ve Önemi”, İstanbul Ticaret Üniversitesi Sosyal Bilimler Dergisi, C: 8, S: 15, s. $89-114$

Ersun, N. ve Arslan, K. (2011). "Turizmde Destinasyon Seçimini Etkileyen Temel Unsurlar ve Pazarlama Stratejileri", Marmara Üniversitesi İ.̇̇.B.F. Dergisi, C: 31, S: 1, s. $229-248$

Hankinson, G. (2004). "The Brand Images of Tourism Destinations: A Study of the Saliency of Organic Images", Journal of Brand Management, Vol: 13, No: 1, p. 146

Howie, F. (2003). Managing The Tourist Destination, London: Thomson Continuum: UK

Huybers, T. and Bennett, J. (2003). "Inter-firm Cooperation At Nature Based Tourism Destinations", The Journal of Socio-Economics, Vol: 32, Issue: 5, p. 573

İlban, M. O., Köroğlu, A. ve Bozok, D. (2008). "Termal Turizm Amaçlı Seyahat Eden Turistlerde Destinasyon İmajı: Gönen Örneği”, İstanbul Ticaret Üniversitesi Sosyal Bilimler Dergisi, Yıl: 7, Sayı: 13, s. 107

İpar, M. S. (2011). "Turizm Destinasyon Markalaşması ve İstanbul Üzerine Bir Uygulama", Yayınlanmamış Yüksek Lisans Tezi, Balıkesir Üniversitesi, Sosyal Bilimler Enstitüsü, Balıkesir, s. 169

Kocaman, S. (2012). "Destinasyon Yönetimi Kapsamında Marka Kimliğine Etki Eden Faktörlerin Marka İmajına Etkisi: Alanya Örneği”, Yayımlanmamış Doktora Tezi, Akdeniz Üniversitesi, Sosyal Bilimler Enstitüsü, Antalya, s. 26

Kotler, P. (2004). “Where Is Place Branding Heading?”, Place Branding, Vol:1, No: 1, p. 12- 35

Kotler, P. and Armstrong, G. (2006). Principles of Marketing, 11th Ed., Prentice Hall: USA

Kotler, P., Bowen, J. ve Maken, J. (2006). Marketing For Hospitality And Tourism, Pearson: Prentice Hall: A.B.D.

Öter, Z. ve Özdoğan, O. N. (2005). "Kültür Amaçlı Seyahat Eden Turistlerde Destinasyon İmajı: Selçuk-Efes Örneği”, Anatolia: Turizm Araştırmaları Dergisi, Cilt: 16, Sayı: 2, s. 127-138

Özer, Ö. (2012). "Destinasyon Tercihinde Pazarlama Karması Bileşenlerinin Rolü: Dalyan Örneği”, İşletme Araştırmaları Dergisi, C: 4, S: 1, s. 163-182

Sarma, M. K. (2014). "Towards Positioning A Tourist Destination: A Study of North East India", Asean Journal on Hospitality and Touirsm, Vol: II, p. 104

Yavuz, M. C. (2007). "Uluslararası Destinasyon Markası Oluşturulmasında Kimlik Geliştirme Süreci: Adana Örneği, Yayınlanmamış Doktora Tezi”, Çukurova Üniversitesi, Sosyal Bilimler Enstitüsü, Adana, s. 49

Yükselen, C. ve Güler, G. E. (2009). Antakya Marka Kent Görüş ve Öneriler, Detay yayıncılık: Ankara 